\title{
Values, Attitudes and Energy Saving Behaviour in Lithuania
}

\author{
VIDAS VILČINSKAS \\ Kaunas University of Technology, 37-1105 A. Mickevičiaus Street, 44244 Kaunas, Lithuania \\ Email: vidas.vilcinskas@ktu.lt
}

\begin{abstract}
Individual behaviour has a significant role to play in reducing the negative impacts of climate change. The energy sector is a significant component impacting climate. Although individual energy saving behaviour can be perceived as something detached from climate change, it is important because of its impact and is therefore the subject of research. The aim of this study is to identify the main factors influencing energy saving behaviour in Lithuania. The Theory of Planned Behaviour and the Theory of Basic Human Values are tested using the European Social Survey Round 8 data. The results show that intention to save energy is the most important factor influencing behaviour. Values are also a strong predictor of energy saving behaviour. Attitudes towards climate change and perceived behavioural control have only a very weak relationship with behaviour.
\end{abstract}

Keywords: environmental behaviour, energy consumption behaviour, Theory of Planned Behaviour, Theory of Basic Human Values, European Social Survey

\section{INTRODUCTION}

There is no reasonable doubt that climate change is occurring on a global scale and is mainly caused by human activities, especially after the publication of the latest report of the Intergovernmental Panel on Climate Change (IPCC 2018). Most climate scientists agree to this issue. Since the world will be affected by climate change, it is important to talk about adaptation and mitigation processes. Pro-environmental individual behaviour is one of the measures that can help reduce the negative impacts of climate change. This type of behaviour is manifested in the individual's preference for environment-friendly alternatives over less environment-friendly alternatives. For example, S. Bamberg and J. Rees (2015) distinguish 4 main types of environmental behaviour: shopping behaviour, recycling behaviour, energy and water saving behaviour and mobility-transportation behaviour. In this research paper, the focus is on energy saving behaviour. The energy sector is considered the most important in the Climate Change Program under the Environmental Projects Management Agency under the Ministry of Environment of the Republic of Lithuania (Aplinkos projektų... 2021). According to Y. Parag (2015), individual energy consumers will play a greater role in the future as '... ability to provide adequate, reliable and affordable energy without harming the environment - will rely on greater engagement of consumers in the system, on capabilities to 
reduce overall demand and on effectively manage demand side'. According to P. Stern (2008), 'environmentally significant behaviour can be defined either by its impact or by its intent'. Although energy saving behaviour, from the consumers' point of view, might not be directly related to climate change, it is still important because of its impact.

This work falls into the field of sociology. In this context, it is important to introduce climate change attitude-behaviour gap term. This term stands for cases where pro-environmental attitudes are present, but pro-environmental behaviour is not carried out. By understanding why this gap occurs, pro-environmental behaviour can be encouraged. However, there is a problem here because there are different theoretical frameworks and factors that influence different behaviours, and the results of studies are not consistent. Therefore, the aim of this study is to identify the most important factors that influence energy saving behaviour in Lithuania. For this purpose, a representative data set is used, which has not been sufficiently studied on this topic.

The Theory of Planned Behaviour (TPB) (Ajzen 1991), along with the Theory of Basic Human Values (TBHM) (Schwartz 2012), serve as the theoretical framework for this study. These theories are commonly used in the social sciences and humanities (Giampietri et al. 2018; Giménez, Tamajon 2019), but behavioural studies do not typically explore the theories together.

This work has aspects in common with several other studies that have applied similar approaches to the Lithuanian population. I. Budraite (2015) applied TPB to household recycling behaviour using qualitative data. G. Liobikienè, J. Mandravickaitè and J. Bernatonienè (2016) tested the TPB on green purchasing behaviour in the European Union (EU). M. Poškus (2016) tested both the TPB and the effect of values on 4 behaviours, one of which is electricity conservation behaviour. The analysis was carried out by means of a survey among students. A. Balundè, G. Perlavičiūtè and L. Steg (2019) investigated the effect of values on different types of behaviours in Lithuania. G. Liobikienè and R. Juknys (2016) investigated the impact of values on pro-environmental behaviours in their study. In addition, factor analysis and regression analysis were used - a method similar to the current study. G. Liobikiené, J. Liobikas, J. Brizga and R. Juknys (2020) specifically investigated the influence of materialistic values on conservation and princely behaviour. M. Jakučionytė-Skodienè, R. Dagiliūtè and G. Liobikienè (2020) examined aspects of energy saving behaviour, including attitudes toward a behaviour variable. The current study is valuable because a different dataset was used than in the previous research and because both the TPB and TBHM approaches were used along with statistical analysis techniques to analyse energy saving behaviour.

The European Social Survey (ESS) (2017) data on perceptions of climate change in Lithuania is used. In the analysis part, principal component analysis, correlation analysis and multiple linear regression analysis are performed. This allows a better understanding of the factors explaining energy saving behaviour in the context of climate change.

\section{THEORETICAL FRAMEWORK}

In this section, the main aspects of the Theory of Planned Behaviour and the Theory of Basic Human Values will be briefly presented. Furthermore, the measures of the variables are described. In addition, the hypotheses are presented.

\section{Theory of Planned Behaviour}

TPB is one of the most frequently used approaches to explain social behaviour (Giampietri et al. 2018). It is also relevant for attitude-behaviour gap research. However, this approach 
has evolved over time. According to I. Ajzen (1991), 'the theory of planned behaviour is an extension of the theory of reasoned action made necessary by the original model's limitations in dealing with behaviours over which people have incomplete volitional control'. In this case, the theory explains social behaviours that arise from an individual's internal feelings and beliefs. External factors that may influence individual behaviour are not considered.

The approach consists of 5 main variables: behaviour, intention, attitude, subjective norms and perceived behavioural control. According to Ajzen (1991), 'as in the original theory of reasoned action, a central factor in the theory of planned behaviour is the individual's intention to perform a given behaviour'. Furthermore, 'intention is reflected in a person's willingness and how much effort that individual is planning to exert to perform the behaviour' (IResearchNet, n.d.). For example, a person will not intend to drive an electric vehicle (EV) if there is no positive attitude towards this action, e.g. due to prejudice towards a new product, as the market share of EVs is still small. Another barrier to EV adoption can be social pressure. For example, as significant others express their scepticism towards EVs. Perceived behavioural control can also be a barrier, for example, if individuals consider EVs to be too expensive. But external factors can also play a role. Despite the intention to use an electric car, the action may not be performed, e.g. because the infrastructure is not in place. This also illustrates that governments can play an important role in the green behaviour of individuals. In the model, intentions lead directly to behaviour. As in the model, attitudes, subjective norms and perceived behavioural control can have a direct impact on intentions.

\section{Theory of Basic Human Values}

Similar to the TPB in terms of its frequent use for behavioural studies it is also true for the present theory, as 'Shalom Schwartz's Theory of Basic Human Values is one of the most commonly used and tested transcultural theories in the field of behavioural research' (Giménez, Tamajon 2019). According to S. Schwartz (2006), values can generally be considered as 'desirable, trans-situational goals, varying in importance, that serves as guiding principles in people's lives'. They are based on beliefs, motivational constructs, abstract goals, etc. Schwartz's value model consists of four main dimensions, which include 10 types of values.

The first dimension openness to change consists of self-direction and stimulation values. According to S. Schwartz (2012), self-direction values are defined by 'independent thought and action-choosing, creating, exploring. Stimulation values are defined by 'excitement, novelty, and challenge in life. Hedonism is associated with both openness to change and self-enhancement dimensions. It is defined by 'pleasure or sensuous gratification for oneself'. Self-enhancement dimension additionally consists of achievement and power values. Achievement is understood as 'personal success through demonstrating competence according to social standards'. Power is defined by 'social status and prestige, control or dominance over people and resources'. According to the theory, conservation dimension is seen as the opposite for openness to change. It consists of security, conformity and tradition values. Security values are defined by 'safety, harmony, and stability of society, of relationships, and of self'. Conformity values are defined by 'restraint of actions, inclinations, and impulses likely to upset or harm others and violate social expectations or norms'. As for traditional values, these are defined by 'respect, commitment, and acceptance of the customs and ideas that one's culture or religion provides'. The latter two types of values are closely interrelated. Finally, self-transcendence dimension, which is considered as opposite to self-enhancement one, consists of benevolence and universalism values. According to the theory, benevolence values are defined by 'preserving and enhancing the welfare of those with whom 
one is in frequent personal contact (the "in-group")'. As for universalism values, these are defined by 'understanding, appreciation, tolerance, and protection for the welfare of all people and for nature'.

\section{Measures and Hypotheses}

For this research paper one dependent variable was selected. It is adopted from the TPB, but for the research purpose it was named as energy saving behaviour. It was measured with a single question: 'There are some things that can be done to reduce energy use, such as switching off appliances that are not being used, walking for short journeys, or only using the heating or air conditioning when really needed. In your daily life, how often do you do things to reduce your energy use?' ( 1 is never; 6 is always). This measures self-observed behaviour.

Four independent variables plus components measuring values are used in the study: energy saving behavioural intentions, climate change attitude, subjective norm, perceived behavioural control and values. Each of the independent variables is measured with a single question, except for values. Later in the study, principal component analysis is applied to extract the main components of values. To measure intentions, responses to the question 'If you were to buy a large electrical appliance for your home, how likely is it that you would buy one of the most energy efficient ones?' ( 0 is not at all likely; 10 is extremely likely) are used. The first of the hypotheses is identified:

H1: There is no statistically significant relation between energy saving behavioural intentions and energy saving behaviour.

The next independent variable is climate change attitude. It was measured by responses to the question: 'To what extent do you feel a personal responsibility to try to reduce climate change?' ( 0 is not at all; 10 is a great deal). The second hypothesis is formulated:

$\mathrm{H} 2$ : There is no statistically significant relation between climate change attitude and energy saving behaviour.

For the subjective norm variable, there are answers to the question: 'It is important to him always to behave properly. He wants to avoid doing anything people would say is wrong' (1 is not like me at all; 6 is very much like me). The hypothesis is formulated as follows:

$\mathrm{H} 3$ : There is no statistically significant relation between subjective norm and energy saving behaviour.

The perceived behavioural control variable is measured by responses to the question: 'Overall, how confident are you that you could use less energy than you do now?' (0 is not at all confident; 10 is completely confident). The fourth hypothesis is the following:

H4: There is no statistically significant relation between perceived behavioural control and energy saving behaviour.

In the study of ESS, values were measured by 21 questions. Principal component analysis is used to classify the values. 2 principal components were extracted which are explained in more detail in the analysis section. The hypothesis is as follows:

$\mathrm{H} 5$ : There is no statistically significant relation between values and energy saving behaviour.

\section{METHODOLOGY}

To identify the aspects influencing self-reported energy saving behaviour in Lithuania, the data from ESS Round 8 (2017) is used. The data from the survey containing questions on 'Public Attitudes to Climate Change, Energy Security, and Energy Preferences' together with measures 
of the 'Human Value Scale' were selected. A structured questionnaire was used to measure the relevant cases. The sample of the study was 2,122 respondents. It is a representative study. And it is also a secondary data analysis. The data was weighted to get precise results (WEIGHT BY dweight). The survey data was analysed using the SPSS statistical software package.

\section{ANALYSIS}

The research paper uses a single dependent variable. It measures energy saving behaviour by asking people how often they do things to reduce energy use. The chart below (Figure) shows the frequency of responses. The majority of respondents tend to engage in energy saving behaviour at least sometimes. From the point of view of environment-friendly behaviour, the result is positive. However, concern about climate change is not particularly high in Lithuania, and social problems are considered the most important by respondents, together with economic problems (Eurobarometer 2019). It is likely that economically based motives play a more important role in this type of behaviour (Steg et al. 2014), although more detailed research would be needed.

The independent variables are also briefly examined. Regarding the climate change attitude (scale 0 to 10 ), $44.1 \%$ of the respondents chose the answer option 5,6 or 7 . Only $15.7 \%$ selected top 3 answers. This shows that although attitudes are positive, they are not particularly high. For the subjective norm (scale 1 to 6), 1-2 response options were chosen by $10.4 \%$ of the respondents, 3-4 were chosen by $49.5 \%$ and $5-6$ were chosen by $40.2 \%$. In describing perceived behavioural control (scale 0 to 10), response options 5, 6 and 7 were selected by $43.3 \%$ of respondents and top 3 responses were selected by $25.4 \%$. For energy saving behavioural intentions (scale 0 to 10 ), $81.3 \%$ of respondents selected response options between 7 and 10 . The intention to save energy is comparatively high, but as with the behaviour case, economic motives are likely to play the most significant role.

\section{Principal Component Analysis}

Principal component analysis is performed with the aim of extracting the main components of the values. These components are used to identify the relationship between the values and the dependent variable. 21 variables for values are used for the analysis.

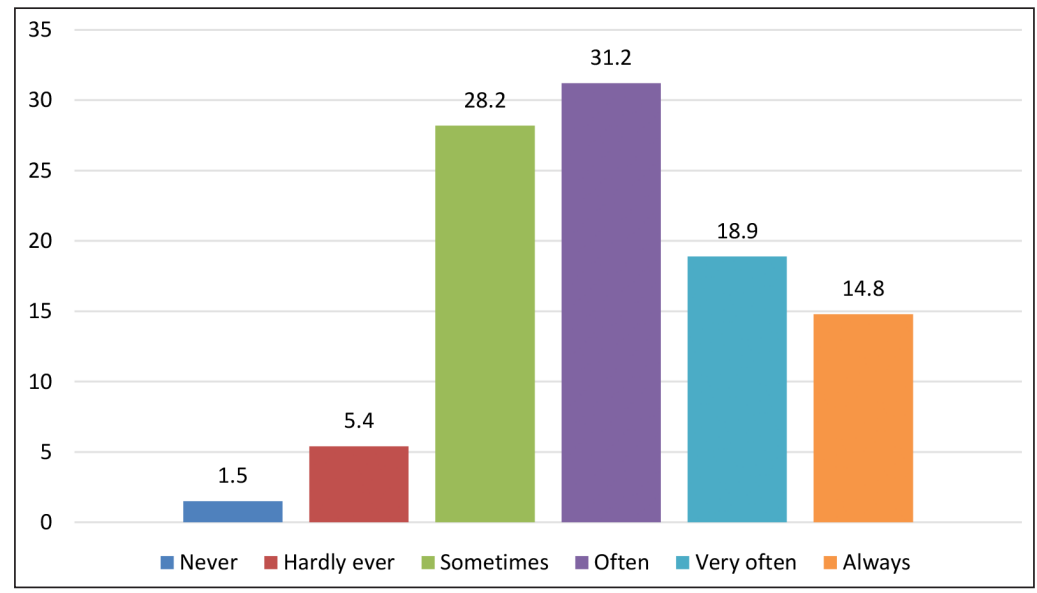

Figure. How often people do things to reduce energy use, percentage, $N=2061$ (1 is never; 6 is always) 
The primary principal component analysis model is constructed, and 3 principal components are extracted. However, these components are not significant because most variables do not have a strong relationship with the components (coefficient value $<0.6$ ). The model is updated by restricting the analysis to 2 components. The updated model is redesigned again as 4 variables do not have a strong relationship with any of the components. The following variables are removed: important to understand different people, important to make own decisions and be free, important to be successful and recognized for achievements, important to be loyal to friends and closely devoted to people.

The best model of principal component analysis is examined. For a component analysis to be valid, it must meet certain assumptions. First, according to Bartlett's Test of Sphericity, the variables are statistically significantly correlated with each other $(p=0.000<0.05)$. Also, the KMO criterion is $0.919>0.6$, so the data is suitable for principal component analysis. The measure of sampling adequacy (MSA) values for the variables is higher than 0.5 , so all the variables used are suitable for analysis. Based on the data, it is appropriate to extract 2 components as Initial Eigenvalues are 6.179 and 3.283, respectively $(>1)$. These 2 components explain $55.661 \%$ of the variance of all variables.

In addition, a rotation of the components is performed. In this way, the structure of the components is optimised. For the component rotation, the Varimax method with Kaiser normalisation is used. The variable is considered to be strongly related to one of the components if the weight is greater than 0.6 . All variables are strongly associated with one of the two factors (Table 1).

Table 1. Weights of the variables

\begin{tabular}{ccc}
\hline Variable & F1 & F2 \\
\hline Important to think new ideas and being creative & 0.171 & 0.711 \\
\hline Important to be rich, have money and expensive things & 0.081 & 0.746 \\
\hline Important that people are treated equally and have equal opportunities & 0.731 & 0.169 \\
\hline Important to show abilities and be admired & 0.306 & 0.728 \\
\hline Important to live in secure and safe surroundings & 0.755 & 0.170 \\
\hline Important to try new and different things in life & 0.040 & 0.792 \\
\hline Important to do what is told and follow rules & 0.602 & 0.174 \\
\hline Important to be humble and modest, not draw attention & 0.647 & -0.232 \\
\hline Important to have a good time & 0.209 & 0.761 \\
\hline Important to help people and care for others well-being & 0.706 & 0.163 \\
\hline Important that government is strong and ensures safety & 0.731 & 0.205 \\
\hline Important to seek adventures and have an exciting life & -0.067 & 0.768 \\
\hline Important to behave properly & 0.760 & 0.047 \\
\hline Important to get respect from others & 0.614 & 0.343 \\
\hline Important to care for nature and environment & 0.782 & 0.195 \\
\hline Important to seek fun and things that give pleasure & 0.673 & -0.106 \\
\hline
\end{tabular}


Applying Schwartz's Theory of Basic Human values, the F1 component is strongly associated with the variables reflecting the values of self-transcendence and conservation. The F2 component, on the other hand, is strongly related to the variables reflecting openness to change and values of self-enhancement. Similar results were obtained by G. Liobikienè and R. Juknys (2016) by applying factor analysis on the values in the Lithuanian population. In this case, two components were identified: self-enhancement and self-transcendence. However, the approach was slightly different.

\section{Correlation Analysis}

Correlation analysis was conducted with the dependent variable energy saving behaviour and the independent variables energy saving behavioural intentions, attitude towards climate change, subjective norm and perceived behavioural control, component F1 and component F2. This type of analysis is included in the study because one of the requirements for regression analysis is for variables to be statistically significant. Therefore, it is considered as part of the regression analysis. However, this type of analysis allows us to examine which variables are not related to the dependent variable, which is also valuable. The results can be seen in the following table (Table 2).

For climate change attitudes, the relationship with the dependent variable is positive and very weak. The relationship with subjective norm is positive and weak. The relationship with perceived behavioural control is positive and weak. The relationship between energy saving behavioural intentions and the dependent variable is positive and weak. For component F1, the relationship is negative and weak. The relationship between component F2 is positive and very weak. All variables have a statistically significant relationship with the dependent variable and were therefore included in the regression analysis.

A. Balundè, G. Perlavičiūtè and L. Steg (2019) included value orientations and behaviours when conducting a correlational analysis on the Lithuanian population. Although the theoretical approach to values in the study is somewhat different, the results can be at least partially compared through an adjustment. In the study, a positive relationship was found between biospheric values and recycling, environmental activism and fuel-efficient driving behaviour, as well as the positive relationship between altruistic values and environmental activism behaviour. This type of values is part of component F1. Meanwhile, a negative relationship was found between hedonic values and recycling with environmental activism behaviour. Also, egoistic values hold a negative relationship with environmental activism and

Table 2. Correlation analysis with dependent variable, $N=1503$

\begin{tabular}{ccc}
\hline Statement & $\begin{array}{c}\text { Correlation coefficients } \\
\text { (Spearman's rho) }\end{array}$ & $\boldsymbol{P}=$ \\
\hline Climate change attitude & $0.179^{\star}$ & $0.000(p<0.05)$ \\
\hline Subjective norm & $0.264^{\star}$ & $0.000(p<0.05)$ \\
\hline Perceived behavioural control & $0.201^{\star}$ & $0.000(p<0.05)$ \\
\hline Energy saving behavioural intentions & $0.337^{\star}$ & $0.000(p<0.05)$ \\
\hline Component F1 (self-transcendence, conservation) & $-0.312^{\star}$ & $0.000(p<0.05)$ \\
\hline
\end{tabular}

* Statistically significant relation. 
sustainable transportation use behaviour. These values are part of component F2. The correlation coefficients were also lower in the latter case. In conclusion, the current study is at least partially consistent with these results.

\section{Regression Analysis}

For a better understanding of the aspects that explain energy saving behaviour, a multiple linear regression model was created. It allows us to understand the relationship between the dependent variable and the independent variables:

- Climate change attitude;

- Subjective norm;

- Perceived behavioural control;

- Energy consumption behavioural intentions;

- Component F1;

- Component F2.

The model statistically significantly explains energy saving behaviour $p=0.000<0.05$. $F=84.020 ; d f=6 . R=0.502 . R$ square $=0.252$. Adjusted $R$ square $=0.249$. The model explains $25 \%$ of energy saving behaviour.

The table below (Table 3) lists the statistically significant regressors that influence energy saving behaviour (in sequence, according to the highest beta coefficient):

- Energy saving behavioural intentions (beta $=0.281$ );

- Component F1 (beta $=-0.250)$;

- Component F2 (beta = 0.146);

- Climate change attitude (beta $=0.100)$;

- Perceived behavioural control (beta $=0.099$ ).

The regression analysis revealed that subjective norm is not a statistically significant predictor of the behaviour. Hypothesis 3 is accepted, as there is no relation between the variables. Energy saving behavioural intentions are the most statistically significant predictor. The higher the behavioural intentions are, the more frequent the behaviour is. Additionally, climate change attitude and perceived behavioural control are also significant predictors. The higher the attitude and perceived control, the more frequent the behaviour. The rest of the hypothesis $\mathrm{H} 1, \mathrm{H} 2, \mathrm{H} 4$ and $\mathrm{H} 5$ are rejected. All of the latter approaches have relation with the dependent variable. It should be noted that the analysis was conducted by integrating the two theoretical approaches, i.e. TPB and TBHV, into a single model. This is important because adding or replacing one variable with another may change the results.

Table 3. Multiple linear regression model coefficients, $N=1503$

\begin{tabular}{ccccc}
\hline Statement & Coefficient B (Std. Error) & Beta & $P=$ \\
\hline Climate change attitude & $0.043(0.011)$ & 0.100 & $0.000^{*}$ \\
\hline Subjective norm & $0.061(0.033)$ & 0.065 & 0.062 \\
\hline Perceived behavioural control & $0.045(0.012)$ & 0.099 & $0.000^{*}$ \\
\hline Energy saving behavioural intentions & $0.160(0.013)$ & 0.281 & $0.000^{*}$ \\
\hline Component F1 (self-transcendence, conservation) & $-0.289(0.040)$ & -0.250 & $0.000^{*}$ \\
\hline Component F2 (openness to change, self-enhancement) & $0.172(0.027)$ & 0.146 & $0.000^{*}$ \\
\hline
\end{tabular}

\footnotetext{
* Statistically significant relation.
} 
Compared to this study, different results were discovered in Lithuania in the case of green purchase behaviour, where the subjective norm had a positive and weak influence on the behaviour (Liobikienè et al. 2016). Subjective norm has been shown to be an important determinant of energy saving behavioural intentions (Mansor, Sheau-Tingi 2019). Moreover, these results differ from the findings of M. Poškus (2016), where no relationship was found between students' attitudes and their behaviours. However, in the current study, the relationship is very weak. Results on the influence of attitudes on energy saving behaviours vary between studies, with some finding a relationship (Mansor, Sheau-Tingi 2019), and others not (Webb, et al. 2013). Behavioural intentions were the most important predictor of behaviour. Behavioural intentions consistently predicted self-reported behaviour across studies. However, in M. Poškus' (2016) study, perceived behavioural control is a significant predictor of behaviour. In this study, the variable has a very weak relationship. Nevertheless, perceived behavioural control is a good predictor of behavioural intentions and energy saving behaviour (Mansor, Sheau-Tingi 2019).

The values are a good predictor of behaviour. The values represented by component F1 are statistically significantly related to the dependent variable. According to the coding of the variables, the higher self-transcendence and conservation values, the more often energy saving behaviour is practised. The values represented by component F2 are also significant. The higher the values for openness to change and self-enhancement, the less frequently energy saving behaviour is practised. This confirms the previous study findings that the corresponding value types lead to more or less environment-friendly behaviour (Liobikienė, Juknys 2016). The aforementioned study by A. Balundè, G. Perlavičiūtè and L. Steg (2019) also confirms these findings. However, not in all instances the relationship between values and behaviours was discovered (Poškus 2016).

\section{CONCLUSIONS}

The study tested two main theories for analysing energy saving behaviour - the Theory of Planned Behaviour and the Theory of Basic Human Values. For the latter, principal component analysis was used, which allowed a dozen value variables to be reduced to a few components. The first component represented the self-transcendence and conservation dimensions of values. The second component represented the openness to change and self-enhancement dimensions of values. The correlation analysis revealed that climate change attitude, subjective norm, perceived behavioural control, energy saving behavioural intentions, and both components were statistically significantly related to the dependent variable energy saving behaviour. However, the further regression analysis revealed that subjective norm was not a significant predictor. The best predictor of behaviour is energy saving behavioural intentions. The higher the intention to perform a behaviour, the more frequent the behaviour. The first component (self-transcendence, conservation) is also an important predictor of behaviour. The higher these values are, the more often the behaviour is performed. In addition, the second component (openness to change, self-enhancement) shows that the higher these values are, the less frequently the behaviour is performed. Climate change attitude and perceived behavioural control variables are statistically significantly associated with a behaviour.

A number of practical implications follow from these results. First, behavioural intentions are the most important independent variable. According to the TPB, this is to be expected. Although the relationship is weak, it means that other contextual factors, as yet unknown, could influence this. This could be due to infrastructure, price of products, availability, etc. Qualitative study methods are needed to investigate this further. In addition, 
the values of self-transcendence and conservation enhance the pro-environmental behaviour. Since value change takes a long time, for example, promoting connectedness with nature and the so-called green identity in school children may lead to a positive outcome in terms of pro-environmental behaviour. Openness to change and values of self-enhancement are also important, albeit as barriers to pro-environmental behaviour. In line with previous studies, these values are associated with materialistic values, which are widespread in Lithuania. In this case, financial incentives can be very successful. An example of this is the deposit return system', which provides an incentive to return used beverage containers for recycling. The factor of perceived behavioural control is also important. Therefore, it should be promoted that every single action is important. Promoting attitudes towards climate change could also lead to positive results.

This work has certain limitations, and these limitations indicate specific areas where more research is needed. The study makes use of a representative data collection, which is beneficial, but the measurements are not precise. As a result, for certain theoretical approaches, a representative research with precise measurements is recommended. In the current study, two commonly used theoretical approaches are used, but they also have their limitations. At the same time, it is not known which approach works best for specific populations. Therefore, it is advisable to apply as many theoretical approaches as possible to specific populations. Moreover, the study focused on the Lithuanian case, although the same approaches may work differently in different populations, so it is advisable to separate and compare them. For the current analysis, a measure of self-observed behaviour is used, but it may not be as accurate as measuring actual behaviour.

Received 14 January 2021 Accepted 23 November 2021

\section{References}

1. Ajzen, I. 1991. 'The Theory of Planned Behavior', Organizational Behavior and Human Decision Processes 50(2): 179-211.

2. Aplinkos projektų valdymo agentūra. 2021. Klimato kaitos programa. Prieiga per internetą: https://www. apva.lt/nacionalines-investicijos/klimato-kaitos-specialioji-programa/apie-programa/

3. Balunde, A.; Perlaviciute, G.; Steg, L. 2019. 'The Relationship Between People's Environmental Considerations and Pro-environmental Behavior in Lithuania, Frontiers in Psychology 10: 2319.

4. Bamberg, S.; Rees, J. 2015. 'Environmental Attitudes and Behavior: Measurement', in International Encyclopedia of the Social and Behavioral Sciences, ed. J. D. Wright. 2nd ed. Elsevier, 699-705.

5. Budraitè, I. 2015. „Kodèl (ne)rūšiuojame? Kokybinè buitinių atliekų rūšiavimo elgseną lemiančių veiksnių analizé, Politologija 77(1): 152-199.

6. ESS. 2017. ESS Round 8. London: European Social Survey.

7. Eurobarometer. 2019. Special Eurobarometer 490. Brussel: European Commission.

8. Giampietri, E.; Verneau, F.; Del Giudice, T.; Carfora, V.; Finco, A. 2018. 'A Theory of Planned Behaviour Perspective for Investigating the Role of Trust in Consumer Purchasing Decision Related to Short Food Supply Chains', Food Quality and Preference 64: 160-166.

9. Giménez, A. C.; Tamajon, L. G. 2019. 'Analysis of the Third-order Structuring of Shalom Schwartz's Theory of Basic Human Values', Heliyon 5(6): 1-7.

10. IPCC. 2018. Intergovernmental Panel on Climate Change. Available at: https://report.ipcc.ch/sr15/pdf/ sr15_spm_final.pdf

11. IResearchNet, n.d. The Theory of Planned Behavior. Available at: https://psychology.iresearchnet.com/ sports-psychology/sport-motivation/the-theory-of-planned-behavior/

12. Jakučionytè-Skodienè, M.; Dagiliūtè, R.; Liobikienè, G. 2020. 'Do General Pro-environmental Behaviour, Attitude, and Knowledge Contribute to Energy Savings and Climate Change Mitigation in the Residential Sector?', Energy 193: 688-696. 
13. Liobikiene, G.; Juknys, R. 2016. 'The Role of Values, Environmental Risk Perception, Awareness of Consequences, and Willingness to Assume Responsibility for Environmentally-friendly Behaviour: The Lithuanian Case', Journal of Cleaner Production 112(4): 3413-3422.

14. Liobikienė, G.; Liobikas, J.; Brizga, J.; Juknys, R. 2020. 'Materialistic Values Impact on Pro-environmental Behavior: The Case of Transition Country as Lithuania', Journal of Cleaner Production 244: 1-10.

15. Liobikienè, G.; Mandravickaite, J.; Bernatonienė, J. 2016. 'Theory of Planned Behavior Approach to Understand the Green Purchasing Behavior in the EU: A Cross-Cultural Study', Ecological Economics 125: 38-46.

16. Mansor, R.; Sheau-Tingi, L. 2019. 'The Psychological Determinants of Energy Saving Behavior', IOP Conference Series: Materials Science and Engineering 620: 012006.

17. Parag, Y. 2015. 'Beyond Energy Efficiency: A "Prosumer Market" as an Integrated Platform for Consumer Engagement with the Energy System, in ECEEE Summer Study Proceedings, 15-23.

18. Poškus, M. S. 2016. 'Investigating Pro-environmental Behaviors of Lithuanian University Students', Current Psychology 37: 225-233.

19. Schwartz, S. H. 2006. Basic Human Values: Theory, Methods, and Applications. Available at: https://yourmorals.org/schwartz.2006.basic\%20human\%20values.pdf

20. Schwartz, S. H. 2012. 'An Overview of the Schwartz Theory of Basic Values', Online Readings inPsychology and Culture 2(1): 1-20.

21. Steg, L.; Bolderdijk, J. W.; Keizer, K.; Perlaviciute, G. 2014. 'An Integrated Framework for Encouraging Pro-environmental Behaviour: The Role of Values, Situational Factors and Goals', Journal of Environmental Psychology 38: 101-115.

22. Stern, P. C. 2008. 'Environmentally Significant Behavior in the Home', in The Cambridge Handbook of Psychology and Economic Behaviour. Cambridge: Cambridge University Press, 363-382.

23. Webb, D.; Soutar, G. N.; Mazzarol, T.; Saldaris, P. 2013. 'Self-determination Theory and Consumer Behavioural Change: Evidence from a Household Energy-saving Behaviour Study', Journal of Environmental Psychology 35: 59-66.

VIDAS VILČINSKAS

\title{
Aplinkosauginių nuostatų ir elgsenos atotrūkis: energijos taupymo atvejis Lietuvoje
}

\begin{abstract}
Santrauka
Individuali žmonių elgsena turi vaidinti reikšmingą vaidmenị mažinant neigiamas klimato kaitos pasekmes. Energetikos sektorius yra svarbus komponentas, turintis įtakos klimatui. Nors individuali energijos taupymo elgsena gali būti suvokiama kaip nesusijusi su klimato kaita, ji svarbi dèl poveikio aplinkai, todèl yra šio tyrimo objektas. Tyrimu siekiama identifikuoti pagrindinius veiksnius, turinčius įtakos energijos taupymo elgsenai Lietuvoje. Planuotos elgsenos teorija kartu su Žmogiškųjų vertybių teorija testuojama pasinaudojus Europos socialinio tyrimo 8 bangos duomenimis. Rezultatai rodo, kad ketinimas taupyti energiją yra svarbiausias veiksnys, turintis ịtakos elgsenai. Vertybès taip pat yra svarbus veiksnys, prognozuojantis energijos taupymo elgseną. Klimato kaitos nuostatos ir suvokiama elgesio kontrole turi tik labai silpną ryši su elgsena.
\end{abstract}

Raktažodžiai: aplinkosauginè elgsena, energijos vartojimo elgsena, Planuotos elgsenos teorija, Žmogiškųjų vertybių teorija, Europos socialinis tyrimas 